DOI 10.15290/cnisk.2020.02.09.06

\author{
JUSTYNA ZAJKO-CZOCHAŃSKA \\ https://orcid.org/0000-0001-6414-8280 \\ Uniwersytet w Białymstoku \\ URSZULA SOKO ŁOWSKA \\ https://orcid.org/0000-0003-2449-4124 \\ Uniwersytet Medyczny w Białymstoku
}

\title{
Listy czytelniczek do „Kobiety i Życia” i „Przyjaciółki” jako źródło badań codziennego życia kobiet $\mathrm{W} \mathrm{PRL}^{1}$
}

\begin{abstract}
Streszczenie
Opracowanie ukazuje istotę listów do redakcji jako źródła badania historii. Na wstępie zaprezentowano definicję analizowanego materiału źródłowego ze wskazaniem przesłanek przemawiajacych za uznaniem korespondencji czytelniczej za autentyczną. Do analizy posłużyły dwa najpopularniejsze czasopisma kobiece okresu PRL: „Przyjaciółka” adresowana do kobiet wiejskich, osób słabo wykształconych, głównie gospodyń domowych, „Kobieta i Życie” zaś do kobiet zamieszkujących miasta, robotnic, nauczycielek czy inteligentek. Wybór tytułów wynika również z faktu, iż to właśnie do obu tych redakcji napływało najwięcej korespondencji, czyniąc je powiernikami ludzkich problemów. Artykuł prezentuje różnorodna tematykę podejmowana w listach do redakcji na łamach obu periodyków, wskazujacc na podobieństwa i różnice w podejmowanych przez czytelników zagadnieniach.

Słowa kluczowe: listy do redakcji, „Przyjaciółka”, „Kobieta i Życie”, prasa kobieca, kobieta w PRL

1 Publikacja przygotowana/finansowana w ramach programu Ministra Nauki i Szkolnictwa Wyższego pod nazwa DIALOG w latach 2019-2021. Jest wynikiem udziału w projekcie badawczym pt. „Ośrodek badań historii kobiet”, nr 0016/DLG/2019/10.
\end{abstract}




\title{
READERS LETTERS FOR KOBIETA I ŻYCIE AND PRZYJACIÓEKA AS A SOURCE OF RESEARCH ON THE DAILY LIFE OF WOMEN IN THE POLISH PEOPLE'S REPUBLIC
}

\begin{abstract}
The study shows the essence of letters to the editor as a source of research on history. At the beginning, the definition of the analyzed source material is presented, with indication of the reasons for considering reading correspondence to be authentic. Two of the most popular women's magazines of the PRL period were used for the analysis. Przyjaciótka [Best Friend] addressed to rural women, poorly educated people, mainly housewives, and Kobieta $i \dot{Z}$ ycie [Woman and Life] to women living in cities, workers, teachers or intellectuals. The choice of titles also results from the fact that it was to both these editors that the most letters were received making them confidants of human problems. The article presents a variety of topics discussed in letters to the editorial staff in both periodicals, indicating similarities and differences in the issues undertaken by readers.
\end{abstract}

Keywords: letters to the editor, Przyjaciótka [Best Friend], Kobieta $i$ Życie [Woman and Life], women's press, women in the Polish People's Republic

\section{Uwagi wprowadzające}

Periodyki „Przyjaciółka” oraz „Kobieta i Życie” w okresie PRL były najbardziej poczytnymi czasopismami kobiecymi. Na popularność pism wpływ miała przede wszystkim ich formuła wydawnicza oparta na listach do redakcji, które od pierwszych numerów stanowiły znak rozpoznawczy „Przyjaciółki”, a także były gatunkiem dziennikarskim utożsamianym z „Kobietą i Życiem”. Jak określa Encyklopedia wiedzy o prasie, list do redakcji to:

forma bezpośredniego wyrażania opinii zbiorowej i indywidualnej za pośrednictwem listu kierowanego do redakcji pisma lecz również przeznaczonego do opublikowania. W ten sposób list do redakcji jest listem i innych czytelników reprezentujących analogiczny pogląd, równocześnie zaś publiczną dyskusją bąź to ze stanowiskiem redakcji pisma, 
bądź też w zwiazku $z$ aktualnym, konkretnym zagadnieniem uznanym przez autora listu za godne powszechnej uwagi... ${ }^{2}$

Szerzej definicję listu do redakcji sformułował Kazimierz Wolny-Zmorzyński, według którego jest to:

Publikowany w prasie tekst autorstwa osoby (osób) niezwiazanej z gazetă, a chcącej podzielić się swymi opiniami na tematy polityczne, kulturalne, społeczne bądź gospodarcze. Bywa i tak, a dzieje się to często, że mając na względzie swoje bezpieczeństwo, autor listu pozostawia swoje dane wyłącznie do wiadomości redakcji ... Podyktowane jest to także tym, że redakcja odpowiada za przekazywane treści na swoich łamach i musi znać personalia tej osoby. Autor listu, decydujacy się na wysłanie go do redakcji, liczy się także $z$ tym, że jego tekst nie będzie w całości wydrukowany: poddany zostanie wewnętrznej redakcji, polegającej na dokonaniu pewnych skrótów, niezbędnych poprawek językowych ... List do redakcji w swej poetyce i formie nawiazuje w pewnym sensie do listu otwartego, przeznaczonego do rozpowszechniania w szerokich kręgach czytelników, i nie ma nic wspólnego $z$ tajemnicą korespondencji3 ${ }^{3}$.

$\mathrm{Na}$ wstępie niniejszego opracowania należałoby odpowiedzieć na pytanie: dlaczego warto badać list do redakcji i czym odróżnia się ta forma wypowiedzi od innych rodzajów źródeł? Według Stefana Krakowskiego list do redakcji posiada trzy charakterystyczne cechy, które (po spełnieniu ich wszystkich łącznie) odróżniaja go od pozostałych źródeł. Pierwszą $z$ nich jest „brak określonego w praktyce celu treściowego źródła”. Należy przez to rozumieć, iż w przeciwieństwie do np. kroniki, obwieszczenia czy supliki list nie posiada określonej treści, czy to opisowo-pośredniej, czy urzędowo-bezpośredniej. Drugą wyróżniającą cecha jest istnienie stosunku na linii nadawca - odbiorca, trzecią zaś, niejako zwiazana $z$ poprzednia, jest utrzymanie dystansu przestrzennego pomiędzy obiema stronami ${ }^{4}$. Podstawowa odpowiedzia na pytanie, dlaczego

\footnotetext{
2 Julian Maślanka (red.), Encyklopedia wiedzy o prasie, (Wrocław-Warszawa-KrakówGdańsk : Zakład Narodowy im. Ossolińskich, 1976), 135.

3 Kazimierz Wolny-Zmorzyński, Andrzej Kaliszewski, Wojciech Furman (red.), Gatunki dziennikarskie. Teoria, praktyka, język, (Warszawa : Wydawnictwo Akademickie i Profesjonalne, 2006), 118-119.

4 Stefan Krakowski, „List jako źródło historyczne. Uwagi w sprawie definicji i kategoryzacji”, Łódzkie Towarzystwo Naukowe. Sprawozdania z czynności i posiedzeń naukowych, R. XL (8), 1986, 5-6.
} 
warto badać listy do redakcji, jest fakt, iż są one doskonałym źródłem do analizy życia codziennego, często nieznanego lub zapomnianego. Przedstawiają one obraz czyjegoś życia, pewnego problemu osobistego lub społecznego czy też historie, które nigdy nie ujrzałyby światła dziennego. Ponadto listy charakteryzuja się rozmaitą treścią, od spraw indywidualnych po ogólnospołeczne, od drobnych kwestii domowych i rodzinnych po problematykę prawną.

Istotnym zagadnieniem, nad którym należy się pochylić, omawiając źródło, jakim jest list do redakcji, jest jego autentyczność. Wiele osób nie traktuje listu jako wiarygodnego źródła. Zarzuca się, iż bywaja preparowane, zakłamuja rzeczywisty stan czy też redakcja pisma nie przedrukowuje wszystkich nadsyłanych listów, ponieważ o ich publikacji decyduje wydawca, kierując się linią czy ideologia pisma ${ }^{5}$. Badając korespondencję nadsyłaną do tygodników „Przyjaciółka” oraz „Kobiety i Życie”, należy również brać pod uwagę warunki, w jakich były one pisane i drukowane. Ze względu na peerelowską cenzurę można domniemywać, iż ich treści były sprawdzane i kontrolowane. Nie tylko odpowiedzi dziennikarzy, ale również drukowane listy nie mogły być sprzeczne $z$ linią polityczna państwa komunistycznego.

Ponadto nie jest już możliwe poddanie kwerendzie listów do „Przyjaciółki”, bo jak stwierdził Marcin Kula, „Archiwum listów "Przyjaciółki" mogłoby być fascynującym materiałem do badania tematów, które obecnie najbardziej interesują historyków. Nie będzie jednak, gdyż w majestacie prawa zostało przemielone jako makulatura" ${ }^{\text {. Podobnie }}$ jest w przypadku „Kobiety i Życie”, gdyż archiwum listów do redakcji nie zachowało się.

Wśród wielu listów przedrukowanych na łamach periodyków istnieja jednak dowody, które wskazuja na ich wiarygodność. Należą do nich widniejące podpisy nadawców zawierające najczęściej imię oraz miejscowość, z której dana osoba pochodzi. Najczęściej były to małe miasteczka lub wsie, w których łatwo o identyfikację. Dodatkowo w samej treści wielokrotnie odnaleźć można było pełne nazwy np. zakładów pracy,

5 Tatiana Szczygłowska, „List do redakcji jako pograniczny gatunek dziennikarski”, $M e-$ dia $i$ społeczeństwo, nr 1, 2011, 87-88.

6 Marcin Kula, Coś trzeba czasem zmienić nawet $w$ archiwach, referat wygłoszony podczas XVII Powszechnego Zjazdu Historyków Polskich - Kraków, 15-18 września 2004 r. [online] [dostęp: 5.02.2020]. Dostępny w World Wide Web: http://jazon.hist.uj.edu.pl/ zjazd/materialy/kula2.pdf. 
które identyfikowały osoby piszące. Ponadto w kolejnych numerach pism ukazywały się kontynuacje podjętego w liście watku czy prośby o interwencję, która redakcja podejmowała, a wymiana korespondencyjna trwała przez kilka numerów. Jednym $z$ przykładów obrazujących jest list:

Chciałabym, aby wszyscy dowiedzieli się, że jesteś prawdziwa przyjaciółka, która każdemu pomoże w biedzie. Twoje interwencje w sprawie otrzymania pracy dały pozytywne wyniki: pracuje w Zakładach Naprawczych w Dąbrowie Górniczej i uczę się w technikum dla pracujących. Spełniły się moje marzenia. Dzięki Tobie uwierzyłam, że są ludzie, którzy pomagaja bezinteresownie. Genowefa D. z Dąbrowy Górniczej ${ }^{7}$.

Jeszcze inna przesłanką przemawiajaca za uznaniem listu do redakcji za wiarygodny materiał źródłowy jest zaszeregowanie go do materiałów autobiograficznych, gdyż jak twierdzi Małgorzata Szpakowska:

jeśli ktoś opowiada o czymś, co mu się wydarzyło, i czyni to w pierwszej osobie, a w dodatku poświadcza swoje słowa podpisem ... choćby pozostawionym tylko do wiadomości redakcji, to wypowiedź taka spełnia wszystkie kryteria formalne. Może być traktowana jako autobiograficzna, nawet gdy jest zdecydowanie nieścisła ${ }^{8}$.

W związku z powyższym, pomimo wielu zarzutów stawianych listom do redakcji, należy przyjąć założenie domniemania ich autentyzmu oraz prawdopodobieństwo opisywanej rzeczywistości, gdyż w przeciwnym wypadku nie miałaby większego sensu ich analiza, a przecież stanowia bogate źródło życia codziennego ludzi.

W celu przygotowania niniejszego opracowania analizie poddano artykuły prasowe „Przyjaciółki” z lat 1956-1975 oraz „Kobiety i Życia”, które ukazywały się w latach 1970-1989. Posłużono się metodą analizy zawartości prasy oraz metoda jakościową. Wykorzystano także metodę porównawcza, wnioskowania oraz syntezy.

\footnotetext{
7 Małgorzata Mroczkowska, Listy do „Przyjaciółki”. Codzienne życie Polaków dekady gierkowskiej w listach czytelników, (Warszawa : Oficyna Wydawnicza Rytm, 2004), 248-249. 8 Małgorzata Szpakowska, „Listy w sprawach osobistych na łamach prasy”, Napis, seria IX, 2003, 233.
} 


\section{Listy do redakcji „Przyjaciółki”}

„Przyjaciółka” była czasopismem, do którego już od pierwszego numeru czytelnicy kierowali korespondencję. Liczba nadsyłanych listów $z$ każdym rokiem była coraz większa i $z$ upływem lat stale rosła. W roku 1952 co dzień do redakcji wpływało przeciętnie 487 listów, sześć lat później ich liczba wzrosła do 600 dziennie ${ }^{9}$. W 1976 roku z okazji 1500 wydania numeru pisma redakcja przedstawiła dane liczbowe dotychczas nadesłanych wiadomości i wysłanych na nie odpowiedzi. W sumie oszacowała:

że kolumna 120 tysięcy listów nadesłanych do nas w ciagu roku i wysyłanych na nie odpowiedzi wysokością dorównywałaby Pałacowi Kultury. Do chwili obecnej otrzymaliśmy 3.300 tys. Waszych listów. Ułożone starannie, jeden po drugim osiagnęłyby wysokość prawie $5 \mathrm{~km}$. Wraz z odpowiedziami daje to kilometrów 10, wysokość $z$ której nawet najwyższy szczyt świata Czomolungma (Mount Everest- 8.848 metrów) nie wydaje się szczególnie imponujacy ${ }^{10}$.

Fenomen listów obiegał wszystkie czasopisma kobiece ukazujące się wówczas na polskim rynku prasowym. Periodyk „Kobieta i Życie”, niejako siostra „Przyjaciółki”, w jednym $z$ numerów pisał:

Egzemplarze „Przyjaciółek” wydrukowane w ciagu jednego tylko roku opasałyby kulę ziemska. Tajemnica niesłabnącego powodzenia tego pisma jest prosty, gawędziarski język, a także - i chyba przede wszystkim - szybka reakcja na troski i bolączki czytelników. Dział Listów i Interwencji to instytucja. Napływa tu rocznie 120 tys. listów - taką liczbą nie może pochwalić się żadne pismo. Prawie połowa zespołu, to pracownicy Działu Listów i Interwencji, wspomagani przez 60 specjalistów z różnych dziedzin: lekarzy, prawników, socjologów, psychologów, kosmetyczki, rolników i ogrodników. Przez 25 lat „Przyjaciółka” odpowiedziała na 3 miliony listów. W każdym numerze około 60 procent artykułów napisanych jest w oparciu o wypowiedzi czytelników,

9 AAN, PZPR KC Wydział Prasy i Wydawnictw, syg. 237/XIX-42, Sprawozdanie z listów za okres od 15.X. do 10.XI.1952 r., k. 47; AAN, PZPR KC Biuro Prasy, syg. 237/XIX-208, Notatka w sprawie fałszywej linii politycznej tyg. „Przyjaciółka”, k. 90.

10 „Drodzy Czytelnicy!”, Przyjaciótka, nr 51, 1976, 3. 
a więc czytelnicy są rzeczywistymi współredaktorami tego pisma. Jest to jedna $z$ tajemnic powodzenia „Przyjaciółki” ${ }^{11}$.

Nadawcami listów byli zwyczajni ludzie, których spotykało się na co dzień. Pisali nastolatkowie, osoby młode i dojrzałe, a także w starszym wieku. Wiadomości wysyłały zarówno kobiety, jak i mężczyźni, których listy stanowiły $30 \%$ całej korespondencji. Pisano z prośba o poradę, pomoc czy o podjęcie interwencji. Inna przyczyną była chęć zwierzenia się $z$ codziennych trosk i osobistych doświadczeń, ale również w celu poznania szerszej opinii na dany temat ${ }^{12}$. Redakcja na łamach czasopisma wielokrotnie zwracała się do swoich czytelników $z$ zachętą nawiązywania przez nich kontaktu. Gwarantowała podjęcie każdego tematu oraz szybką i życzliwą odpowiedź na każde nadesłane pismo ${ }^{13}$.

Na łamach periodyku w listach poruszano różnorodną tematykę. Nie było ludzkiego problemu, $z$ którym nie zwrócono by się do redakcji pisma. Podnoszono tematy konfliktów rodzinnych, problemów $z$ wychowaniem dzieci i dorastaniem nastolatków, relacji z sąsiadami czy kłopotów w gospodarstwie domowym. Pisano o pracy w rolnictwie, o ograniczonych możliwościach wsi, a także (głównie w mutacji miejskiej) o trudnościach napotykanych $\mathrm{w}$ pracy. Wielokrotnie zwracano się z prośbą o poradę w niemal każdej dziedzinie życia, gdyż periodyk opierał się również na bogatej treści poradnikowej.

Ze względu na fakt, iż okres PRL charakteryzował się ogromnym problemem alkoholizmu wśród społeczeństwa, głównie mężczyzn, na łamach listów do „Przyjaciółki” wielokrotnie podejmowano ów temat. Matki i żony w nadsyłanych tekstach przywoływały przykłady konfliktów, a nieraz nawet tragedii rodzinnych wynikajacych $z$ nadmiernego spożywania alkoholu. Ponadto do redakcji kierowane były listy całych grup kobiet ${ }^{14}$, które zwracały się do „Przyjaciółki” o wsparcie w walce z pijanymi mężczyznami, którzy negatywnie wpływali na otoczenie, „gorszyli” miejscowa młodzież. W jednym $z$ listów czytamy:

My kobiety z gromady Wierzchowice - powiat Milicz - prosimy Cię droga „Przyjaciółko”, żebyś nam pomogła zlikwidować bar, zwany mlecznym,

11 „25 lat „Przyjaciółki»”, Kobieta i Życie, nr 11, 1973, 4.

12 Barbara Moroz, Krystyna Łuniewska, Ruta Pragier (oprac.), Sto listów do „Przyjaciótki”, (Warszawa : Krajowa Agencja Wydawnicza, 1980), 3-5.

13 Na przykład Przyjaciółka, nr 1, 1952, 3; Przyjaciółka, nr 2, 1952, 3.

14 „Niepotrzebna gospoda”, Przyjaciótka, nr 37, 1960, 7. 
w którym zamiast mleka sprzedaje się wódkę. Bar ten znajduje się niedaleko szkoły i dzieci nieraz maja bezpłatne, niezbyt kulturalne widowiska. W barze ani koło niego nie ma bowiem ubikacji i pijacy załatwiają swoje potrzeby na ulicy ${ }^{15}$.

Innym problemem polskiej wsi ukazywanym w listach do redakcji głównie w latach 60. XX w. były kwestie zwiąane $z$ elektryfikacja. Nagminnie napływała korespondencja, w której skarżono się na brak światła czy też wodociagów, które stanowiły podstawę dogodnego życia i pracy na wsi. Zarówno kobiety, jak i mężczyźni reprezentujacy daną miejscowość zwracali się do redakcji z prośba o interwencję w tej spra$w_{i e}{ }^{16}$. Problemem społeczności wiejskiej wielokrotnie poruszanym przez czytelników pisma były także konflikty sąsiedzkie. W listach opowiadano zarówno o drobnych sporach, jak i o tych, które często urastały do ogromnej rangi czy nawet kończyły się na wokandzie sądowej ${ }^{17}$.

W latach 60. i 70. XX w. na wsiach prężnie działały Koła Gospodyń Wiejskich, co przekładało się na liczną korespondencję w sprawie ich funkcjonowania. W kierowanych przez członkinie organizacji listach nie brakowało przepełnionych entuzjazmem historii zwiazanych $z$ pozytywnymi działaniami KGW na rzecz samych członkiń, ich rodzin czy otoczenia. Wśród wielu nadsyłanych listów nie sposób pominąć szeregu próśb działaczek adresowanych do dziennikarzy, by ci wstawiali się wśród władz o pomoc w celu pomyślnego załatwiania sprawy, o jaką się zwracały. Członkinie KGW wielokrotnie zabiegały o poprawę dróg dojazdowych do wsi, budowę boiska dla dzieci, świetlic, remont szkoły, a także o zorganizowanie kina objazdowego, które byłoby namiastką życia kulturalnego $\mathrm{wsi}^{18}$. Wspomniany już problem $\mathrm{z}$ alkoholizmem również był częstym tematem podejmowanym w listach do redakcji przez członkinie KGW. Wielokrotnie przywoływano trudności zwiąane $z$ działalnościa Gminnych Spółdzielni. Podkreślano nie tylko niedobory produktów spożywczych czy artykułów przemysłowych, ale przede wszystkim kwestię

15 „Mleko od... wściekłej krowy”, Przyjaciółka, nr 24, 1960, 5.

16 Na przykład „Chcemy zbudować wodociag”, Przyjaciółka, nr 20, 1960, 10; „Zmarnowany wysiłek”, Przyjaciółka, nr 28, 1960, 3.

17 „Czytelnicy pisza, Przyjaciółka odpowiada”, Przyjaciótka, nr 13, 1960, 13; „Czytelnicy pisza, Przyjaciółka odpowiada", Przyjaciółka, nr 27, 1960, 13.

18 Np. „Dla świętego spokoju”, Przyjaciółka, nr 47, 1961, 5; „Załatwione i do załatwienia”, Przyjaciółka, nr 24, 1960, 8-9. 
spożywania w sklepach i w ich pobliżu alkoholu, co negatywnie wpływało na lokalną młodzież i dzieci ${ }^{19}$.

Wśród szerokiego spektrum podejmowanej tematyki w ramach listów do redakcji w najmniejszym stopniu czytelnicy „Przyjaciółki” zwracali się $\mathrm{w}$ sprawach związanych $\mathrm{z}$ polityka, zagadnieniami gospodarczymi czy też aspektami międzynarodowymi. Nieco bardziej wzmożona wymiana korespondencji dotycząca ww. tematów oscylowała w okresie przedwyborczym. Adresaci najczęśsiej kierowali do redakcji podstawowe pytania zwiazane $z$ wyborami, by w sposób prawidłowy oddać głos i zrozumieć samą istotę wybierania władz. Odpowiedzi dziennikarzy były równie proste, co pytania, by mogła je zrozumieć czytelniczka, która należała do osób słabo wykształconych, posiadajacych niewielka wiedzę i świadomość polityczna, gdyż właśnie do takich odbiorców „Przyjaciółka” była kierowana.

\section{Listy do redakcji „Kobiety i Życia”}

Przeznaczenie czytelnicze „Kobiety i Życia” zostało sprecyzowane po wydarzeniach politycznych 1956 r. Od tego momentu redakcja periodyku określiła, iż będzie dobierała teksty w taki sposób, aby wzbudzać zainteresowanie wykształconych mieszkanek miast ${ }^{20}$. Podobnie jak w przypadku „Przyjaciółki”, niezwykle ważna była więź redakcji „Kobiety i Życia” ze swoimi odbiorczyniami. Na łamach pisma wiele miejsca poświęcano listom do redakcji, które najczęściej publikowano w formie plebiscytów czy ankiet. Zespół redakcyjny czasopisma niejednokrotnie zachęcał czytelników do nadsyłania odpowiedzi na zadane pytania, dotyczące bieżącej problematyki.

Zakres tematyczny publikowanych listów był bardzo szeroki. Na potrzeby niniejszego artykułu poruszaną tematykę podzielono na dwie kategorie. Pierwsza $z$ nich to problematyka typowa dla magazynów kobiecych, czyli m.in.: poradnictwo, moda, uroda, gospodarstwo domowe, kulinaria, macierzyństwo oraz małżeństwo. Drugą natomiast stanowiły zagadnienia dotychczas bardzo rzadko poruszane na łamach innych periodyków kobiecych okresu PRL, m.in.: samorealizacja kobiet,

19 „Jak wypędzić tego wroga?”, Przyjaciótka, nr 28, 1960, 12.

20 AAN, KC PZPR Prasy i Wydawnictw, syg. 237/XIX - 208, Uwagi o prasie kobiecej. „Kobieta i Życie”, „Przyjaciółka”, „Zwierciadło”, styczeń - maj 1958 r., k. 1. 
awanse zawodowe, kobiety na kierowniczych stanowiskach oraz ich udział w przestrzeni politycznej, równość i równouprawnienie kobiet i mężczyzn, rozwody, samotne macierzyństwo, antykoncepcja czy zabieg przerywania ciąży. Redakcja czasopisma chętnie odnosiła się do listów dotyczących każdej problematyki, udzielając wskazówek oraz porad. Nie unikano podejmowania spraw trudnych oraz doradzania w kwestiach intymnych i kontrowersyjnych. Intencja autorek artykułu była nie tylko charakterystyka korespondencji publikowanej na łamach „Przyjaciółki” i „Kobiety i Życia”, ale także ukazanie różnic w treści wypowiedzi czytelniczek obu analizowanych periodyków. Dlatego też w dalszej części opracowania omówiono wybrane zagadnienia poruszane w listach do „Kobiety i Życia” - takie, które nie występowały w wypowiedziach odbiorczyń „Przyjaciółki”.

Od poczatku lat 70. XX w., kiedy funkcję redaktor naczelnej objęła Barbara Sidorczuk, coraz silniej upowszechniano tematykę pozycji społecznej Polek oraz ich miejsca w przestrzeni publicznej naszego kraju. Wiele miejsca w czasopiśmie poświęcono zagadnieniom związanym z wszelkimi aspektami aktywności zawodowej kobiet, co znalazło również swoje odbicie wśród publikowanych listów do redakcji. Czytelniczki niejednokrotnie pisały o nierównym traktowaniu w pracy zawodowej oraz stereotypowym podziale na profesje typowo „męskie” i „kobiece”. „Kobieta i Życie" nie stroniła od poruszania trudnej problematyki i publikowania wypowiedzi, które podważały obraz gierkowskiej epoki prosperity lat 70 . XX w. Doskonały przykład stanowi wypowiedź jednej z czytelniczek, która następujacymi słowami opisywała początki swojej kariery w zawodzie lekarza chirurga:

Nie miałam już siły i nie mogłam wytrzymać w tej atmosferze. Nie dopuszczali mnie do operacji. Byłam popychana do najgorszej roboty, najchętniej do narkozy (anestezjologia w ogóle nie istniała) to znaczy, usypianie chorego - a to była istna „kara za grzechy”. Chichotali z zachwytu, gdy operator pastwił się nad biednym „usypiaczem”. Już w zwyczaj weszło pyskowanie, że chory źle śpi, wypycha wszystkie flaki, a taka narkoza to jest w ogóle „do dupy"21.

Autorka powyższego listu $z$ rozżaleniem opisywała stereotypowe postrzeganie kobiet w chirurgii. W dalszej części swojej wypowiedzi

$\overline{21}$ „W męskim zawodzie”, Kobieta i Życie, nr 31, 1974, 4-5. 
podkreślała, że głównym celem, jaki przyświecał jej przy wyborze specjalizacji, była chęć pomocy innym. Nie spodziewała się, że będzie musiała codziennie zmagać się $z$ nieprzychylnym spojrzeniem ze strony swoich kolegów po fachu, którym teoretycznie powinno zależeć na tym samym - zdrowiu swoich pacjentów ${ }^{22}$.

W okresie PRL Polki niejednokrotnie zmagały się $z$ trudnościami w dostępie do kierowniczych stanowisk. Pomimo posiadania jednakowych lub często wyższych kompetencji od swoich współpracowników - mężczyzn wymagano od nich więcej na drodze do uzyskania awansu zawodowego. W opinii wielu czytelniczek uwarunkowane było to głównie czynnikami kulturowymi i obyczajowymi, zakorzenionymi w społeczeństwie polskim:

Ale oczywiście, że kobietom trudniej awansować. Bo przeważnie przy takiej decyzji zaczyna się bredzenie w obłudnie zatroskanym tonie o tym, czego ona na pewno nie zrobi. Więc nie zostanie w pracy jak będzie potrzeba, bo ma dom, męża, dzieci, obiady i przepierki. Weźmie zwolnienie na chore dzieci. Przyjdzie zmęczona i nieskora do pracy. A praca ponad obowiazujące godziny - jeśli jest reguła - to znaczy, że szwankuje organizacja. Dlaczego więc zakłada się z góry, że przy złej organizacji nie sprawdzi się tylko kobieta? ${ }^{23}$

Czytelniczki „Kobiety i Życia”, również te sprawujące funkcje kierownicze, podkreślały $\mathrm{w}$ swoich listach dyskryminację płacowa, czyli otrzymywanie niższego wynagrodzenia od mężczyzn zatrudnionych na równoległych stanowiskach oraz posiadajacych jednakowe obowiazki zawodowe. $\mathrm{W}$ jednym $\mathrm{z}$ listów do redakcji pisano:

Funkcję kierownika sprawuję od 18 lat, ale zawsze moja płaca była niższa od płacy znacznie ode mnie słabszych zawodowo kierowników mężczyzn. Wybitne zdolności organizatorskie, wiedza, permanentnie doskonalona, bezkompromisowa walka o porządek sa przyczynami awansowania mnie na nowe, zabałaganione odcinki pracy $z$ minimalna rekompensata finansowa... Dotyczy to prawie wszystkich wybitnych kobiet kierowników w moim zakładzie, których w randze kierownika działu jest zaledwie kilka ${ }^{24}$.

\footnotetext{
22 Ibidem.

23 „Męski zawód”, Kobieta i Życie, nr 18, 1977, 17.

24 „Równa płaca”, Kobieta i Życie, nr 25, 1976, 5.
} 
Warto zwrócić uwagę, że listy traktujące o negatywnych sytuacjach w miejscach pracy czytelniczek „Kobiety i Życia” wielokrotnie miały podobny układ. Przeważająca część kobiet opisujących dyskryminujące praktyki zawodowe podkreślała swoją determinację oraz upór w dążeniu do wyznaczonego celu, np.: „Już nie wytrzymałam i chciałam odejść ... Jednakże swoim zwyczajem zacięłam się i... przetrzymałam”25. Czytelniczki pisały o trudnościach na swojej drodze zawodowej, jednak zazwyczaj ich wypowiedzi kończyły się pozytywnie. Zwracano uwagę, że pomimo początkowych niedogodności udało się im osiagnać to, co zaplanowały. Autorki listów akcentowały znaczenie ich cech osobowościowych oraz siły charakteru w samorealizacji oraz spełnianiu zawodowych aspiracji. Analiza listów dotyczacych sytuacji zawodowej kobiet oraz fakt, że publikowane wypowiedzi miały podobny charakter, stanowi doskonały dowód na to, iż zamieszczane listy podlegały ciagłej kontroli redakcyjnej.

W pierwszej połowie lat 70. XX w. na łamach tygodnika „Kobieta i Życie" silnie eksponowano problematykę rozwodowa, co bezpośrednio wynikało $z$ ówczesnych procesów społecznych zachodzacych w Polsce. Szeroko zakrojoną dyskusję na temat rozwodów podjęła redakcja czasopisma, poświęcając wiele miejsca na publikację listów od czytelniczek będacych po rozwodzie. W odpowiedziach na ogłoszony w 1974 r. cykl „Życie po rozwodzie” najliczniej występowały wątki dotyczące przyczyn rozpadu małżeństwa. Wśród nich najczęściej kobiety wymieniały alkoholizm swoich mężów. Jak można zauważyć, problematyka alkoholizmu w okresie PRL dotyczyła zarówno środowisk wiejskich - listy do redakcji „Przyjaciółki”, jak i obszarów miejskich - korespondencja czytelniczek „Kobiety i Życia”. Jednakże w „Przyjaciółce” nie podejmowano tematyki rozwodowej, pisząc jedynie o problemie pijaństwa wśród mężczyzn zamieszkujących wsie ${ }^{26}$. Z kolei w latach $70 . \mathrm{XX}$ w. wiele czytelniczek „Kobiety i Życia” opisywało swoja sytuację po rozwodzie, zwracając uwage m.in. na problem zamieszkiwania jednego lokum $z$ byłym małżonkiem.

Wiele autorek listów wskazywało, iż pozostawanie $z$ byłym mężem w jednym mieszkaniu było niekomfortowe i nie zapewniało poczucia

25 „W męskim zawodzie”, 4-5.

26 Taki dobór problematyki wydaje się jak najbardziej uzasadniony i wynika ściśle $z$ faktu, iż w całym okresie powojennej Polski odsetek rozwodów był nieporównywalnie większy w miastach niż na wsiach. Vide: Piotr Szukalski, Małżeństwo. Początek i koniec, (Łódź : Wydawnictwo Uniwersytetu Łódzkiego, 2013), 172. 
bezpieczeństwa zarówno kobiecie, jak i jej dzieciom. Jedna z czytelniczek opisywała:

Moim zdaniem rozwód jest jedynym rozwiązaniem, ale pod warunkiem, że po rozwodzie zamieszka się osobno i nie widuje się. Ja dalej mieszkam we wspólnym mieszkaniu, to znaczy mamy wspólną kuchnię, ubikację, korytarz. Jestem - jak dawniej za czasów naszego małżeństwa - świadkiem, jak były mąż sprowadza sobie 18-latki. Słychać przez cienkie ściany prawie wszystko, ale muszę to znosić, bo nie mam wyboru. Mam 2 dzieci $^{27}$.

W dalszej części wypowiedzi rozwiedziona kobieta zwracała uwagę na negatywny wpływ byłego męża na ich syna: „Rozwód w zasadzie niczego nie zmienił bo mieszkamy w jednym mieszkaniu, w osobnych pokojach. Ja $z$ dziećmi w mniejszym, on sam - w dużym. Nadal więc słyszę, jak wraca późna noca. Nie tylko, że nie pomaga mi wychowywać syna, $z$ którym mam ogromne trudności, ale stale buntuje go przeciwko mnie”28. Inna czytelniczka $z$ kolei pisała: „Były mą̇ sprowadził do domu kochankę. Zachowują się strasznie: wódka, libacje, podejrzani znajomi. Cóż $z$ tego, że ja $z$ dwojgiem dzieci zajmuję oddzielny pokój. Wszystko widać i słychać. Młodsze dziecko $z$ przerażeniem patrzy na to co się dzieje, nie rozumie, co w domu robi ta nie znana dotad ciocia"29.

Rozwiedzione kobiety będące autorkami listów do redakcji omawianego periodyku dzieliły się swoimi najbardziej osobistymi historiami. Wielokrotnie wypowiedziom towarzyszyło uczucie smutku oraz rozczarowania. Jednakże w przeważającej części listów odnaleźć można było przekonanie o słuszności podjętej decyzji o rozwodzie, np.:

Dla mnie rozwód okazał się wyzwoleniem. Jestem wolna. Jestem sobą. Nie żyję już na marginesie własnego życia. Czy jestem szczęśliwa? I tak. I nie. Mam dobre i mądre dziecko. Grono oddanych ludzi. Dom, który jest moim sanktuarium. Niezłą pozycję zawodową. Powodzenie u mężczyzn. Propozycje małżeństwa. A jednak czegoś mi brak ... Byłam kochana. Nie spotkałam jednak mężczyzny, którego ja potrafiłabym pokochać. A bardzo chciałam ... A rozwodzić się - warto było ${ }^{30}$.

27 „Życie po rozwodzie. Pod jednym dachem”, Kobieta i Życie, nr 28, 1974, 13.

28 Ibidem.

29 „Rozwód a mieszkanie”, Kobieta i Życie, nr 14, 1975, 5.

30 „Życie po rozwodzie. Jestem sobą?”, Kobieta i Życie, nr 19, 1974, 5. 


\section{Podsumowanie}

Nie sposób w tym miejscu wymienić i omówić wszystkich zagadnień tematycznych, które znalazły odzwierciedlenie w listach publikowanych na łamach dwóch najbardziej popularnych periodyków okresu PRL - „Przyjaciółki” oraz „Kobiety i Życia”. Dlatego też autorki niniejszego opracowania starały się zaprezentować wybrana problematykę, a jej dobór miał służyć wskazaniu pewnych podobieństw oraz różnic w korespondencji nadsyłanej do redakcji analizowanych czasopism.

Na podstawie analizy listów czytelniczek do redakcji obu czasopism należy stwierdzić, iż zakres tematyczny poruszany w korespondencji był bardzo szeroki. Wśród elementów wspólnych można wyróżnić problematykę typową dla magazynów kobiecych okresu PRL, m.in. gospodarstwo domowe, rodzina, macierzyństwo, moda oraz uroda. W odniesieniu do kwestii społecznych niewątpliwie dużo miejsca w obu periodykach poświęcono temacie alkoholizmu. Jednakże sposób jego ujęcia przez odbiorczynie analizowanych czasopism był różnorodny.

Czytelniczki „Przyjaciółki” w swoich listach najczęściej pisały o organizacji prac w gospodarstwie rolnym, formach spędzania czasu wolnego na wsiach, m.in. działalności Kół Gospodyń Wiejskich. Z kolei odbiorczynie „Kobiety i Życia” chętnie poruszały kwestie związane z modernizacja gospodarstw domowych, aktywnościa zawodowa kobiet, ich miejscem w przestrzeni politycznej, antykoncepcja czy rozwodami. Odmienna tematyka listów związana była $z$ gronem adresatów poszczególnych czasopism. Naturalne było, iż czytelniczki wypowiadały się w kwestiach, które dotyczyły ich w największym stopniu. Takich, które odnosiły się do bieżących problemów w społecznościach lokalnych. W przypadku „Przyjaciółki” - obszarów wiejskich, „Kobiety i Życia” - środowisk miejskich.

Czynnikiem łączącym wypowiedzi czytelniczek analizowanych pism była chęć zaprezentowania swoich poglądów. Najczęściej dotyczyły one kwestii, które w danym momencie najbardziej zajmowały uwage autorek listów, dotyczyły problematyki poruszanej w periodyku lub korespondencji innych czytelników. $Z$ jednej strony, czytelniczki prezentowały swoje opinie. $Z$ drugiej natomiast, zespół redakcyjny poprzez wybór tekstów, które ukazywały się drukiem, mógł wpływać na linię danego periodyku.

Poprzez zamieszczanie określonych listów czytelniczek redakcja upowszechniała konkretne postawy społeczne czy sposób postępowania. 
Zatem zamieszczane w „Przyjaciółce” oraz „Kobiecie i Życiu” wypowiedzi nie tylko odzwierciedlały opinię publiczną danej grupy - kobiet ze środowisk wiejskich i miejskich, ale także skutecznie obrazowały zabiegi dziennikarzy i wydawców chcących propagować konkretne wzorce i normy społeczne.

Biorąc pod uwage peerelowską cenzurę oraz analizę listów publikowanych na łamach obu periodyków, należy stwierdzić, iż ich treść podlegała nieustannej kontroli. Publikowane materiały, jak również odpowiedzi pracowników redakcji nie mogły pozostawać sprzeczne $z$ odgórnymi wytycznymi aparatu władzy. Co nie zmienia faktu, iż wypowiedzi czytelniczek „Przyjaciółki” i „Kobiety i Życia” publikowane w kolejnych wydaniach periodyków stanowią bogate źródło badań codziennego życia kobiet w PRL.

\section{Bibliografia}

\section{Źródła}

AAN, KC PZPR Prasy i Wydawnictw, syg. 237/XIX - 208, Uwagi o prasie kobiecej. „Kobieta i Życie”, „Przyjaciółka”, „Zwierciadło”, styczeń-maj 1958 r., k. 1.

AAN, PZPR KC Biuro Prasy, syg. 237/XIX-208, Notatka w sprawie fałszywej linii politycznej tyg. „Przyjaciółka”, k. 90.

AAN, PZPR KC Wydział Prasy i Wydawnictw, syg. 237/XIX-42, Sprawozdanie z listów za okres od 15.X. do 10.XI.1952 r., k. 47.

„25 lat „Przyjaciółki»”, Kobieta i Życie, nr 11, 1973, 4.

„Chcemy zbudować wodociag”, Przyjaciótka, nr 20, 1960, 10.

„Czytelnicy pisza, Przyjaciółka odpowiada”, Przyjaciótka, nr 13, 1960, 13.

„Czytelnicy pisza, Przyjaciółka odpowiada”, Przyjaciółka, nr 27, 1960, 13.

„Dla świętego spokoju”, Przyjaciótka, nr 47, 1961, 5.

„Drodzy Czytelnicy!”, Przyjaciółka, nr 51, 1976, 3.

„Jak wypędzić tego wroga?”, Przyjaciółka, nr 28, 1960, 12.

„Męski zawód”, Kobieta i Życie, nr 18, 1977, 17.

„Mleko od... wściekłej krowy”, Przyjaciółka, nr 24, 1960, 5.

„Niepotrzebna gospoda”, Przyjaciółka, nr 37, 1960, 7.

„Rozwód a mieszkanie”, Kobieta i Życie, nr 14, 1975, 5.

„Równa płaca”, Kobieta i Życie, nr 25, 1976, 5. 
„W męskim zawodzie”, Kobieta i Życie, nr 31, 1974, 4-5.

„Załatwione i do załatwienia”, Przyjaciółka, nr 24, 1960, 8-9.

„Zmarnowany wysiłek”, Przyjaciółka, nr 28, 1960, 3.

„Życie po rozwodzie. Jestem sobą?”, Kobieta i Życie, nr 19, 1974, 5.

„Życie po rozwodzie. Pod jednym dachem”, Kobieta i Życie, nr 28, 1974, 13.

Krakowski, Stefan. „List jako źródło historyczne. Uwagi w sprawie definicji

i kategoryzacji”, Łódzkie Towarzystwo Naukowe. Sprawozdania z czyn-

ności i posiedzeń naukowych, R. XL (8), 1986, 5-6.

Przyjaciótka, nr 1, 1952, 3.

Przyjaciółka, nr 2, 1952, 3.

Szczygłowska, Tatiana. „List do redakcji jako pograniczny gatunek dzienni-

karski”, Media i społeczeństwo, nr 1, 2011, 87-88.

Szpakowska, Małgorzata. „Listy w sprawach osobistych na łamach prasy”, Napis, seria IX, 2003, 233.

\section{Opracowania}

Maślanka, Julian (red.), Encyklopedia wiedzy o prasie, (Wrocław-WarszawaKraków-Gdańsk : Zakład Narodowy im. Ossolińskich, 1976).

Moroz, Barbara. Łuniewska, Krystyna. Pragier, Ruta (oprac.), Sto listów do „Przyjaciółki”, (Warszawa : Krajowa Agencja Wydawnicza, 1980).

Mroczkowska, Małgorzata. Listy do „Przyjaciótki”. Codzienne życie Polaków dekady gierkowskiej w listach czytelników, (Warszawa : Oficyna Wydawnicza Rytm, 2004).

Szukalski, Piotr. Małżeństwo. Początek i koniec, (Eódź : Wydawnictwo Uniwersytetu Łódzkiego, 2013).

Wolny-Zmorzyński, Kazimierz. Kaliszewski, Andrzej. Furman, Wojciech (red.), Gatunki dziennikarskie. Teoria, praktyka, język, (Warszawa : Wydawnictwo Akademickie i Profesjonalne, 2006).

\section{Publikacje internetowe}

Kula, Marcin. Coś trzeba czasem zmienić nawet w archiwach, referat wygłoszony podczas XVII Powszechnego Zjazdu Historyków Polskich - Kraków, 15-18 września 2004 r. [online] [dostęp: 5.02.2020]. Dostępny w World Wide Web: http://jazon.hist.uj.edu.pl/zjazd/materialy/kula2.pdf. 